\title{
China's Global Expansion and Latin America
}

\author{
RHYS JENKINS
}

Abstract. China's rapid growth and increased integration with the global economy over the past three decades have significant economic impacts and political implications for Latin America. This paper reviews the debate over whether these impacts have on balance been positive or negative for the region. It argues that those who emphasise the positive economic impacts of China have been over-optimistic and underplay some of the negative impacts associated with Chinese competition in manufacturing and increasing Latin American specialisation in primary products. On the other hand, when focusing on the political dimensions, there has been a tendency to exaggerate both the extent of China's influence in the region and the fears to which this gives rise, particularly among US commentators.

Keywords: China, Latin America, trade, foreign investment, competition, US hegemony, democracy

\section{Introduction}

China's rapid economic growth and increased openness has been one of the most significant developments in the global economy over the past three decades. This re-emergence of China dates from the late r970s, when Deng Xiaoping began the process of reform and economic opening. While Latin America entered a decade of economic stagnation in the I980s, China was starting a period of rapid economic growth. Since i 980 the Chinese economy has grown at almost io per cent per annum, and as a result per capita income has increased sevenfold. China is now poised to overtake Japan as the second-largest economy in the world, behind the United States.

As well as experiencing rapid growth, China also became much more integrated with the global economy. Its share of global trade rose from less than I per cent in I980 to around 8 per cent, and in 2009 it became the world's largest exporter ahead of Germany. China's growing trade surplus led to the accumulation of large foreign exchange reserves and to the country

Rhys Jenkins is Professor of International Development at the University of East Anglia. Email: r.o.jenkins@uea.ac.uk. 
becoming a major purchaser of US treasury bonds. China has also become a major destination for foreign direct investment (FDI), accounting for over 5 per cent of global FDI inflows between 2005 and 2008. ${ }^{1}$ Although it is starting from a low base, outward investment from China is growing rapidly and several Chinese companies have become important global players, particularly in the extractive industries.

Although China's rapid growth is not unprecedented, showing similarities with earlier growth episodes in Japan, South Korea and Taiwan, what is different about China is the sheer size of its economy. This means that the increased competitiveness of China and its expanded presence in world markets is having a major impact on both developed and developing countries. It has been estimated that China accounted for i 2.8 per cent of world economic growth between 1995 and 2004, and this has been projected to rise to 15.8 per cent for the period $2005-20 .^{2}$ With the world recession, China's contribution to global growth has taken on even greater significance.

China's economic rise has also led to it becoming a much more significant player in global politics, as was highlighted by its role in the Copenhagen Conference on Climate Change in December 2009. China has, of course, long had a privileged position as a permanent member of the United Nations Security Council, but in recent years it has become more directly involved in other institutions of global governance such as the G-20, the World Trade Organisation (WTO), the International Monetary Fund and the World Bank. It has also aligned itself with other large emerging economies, forming the so-called BRICs with Brazil, Russia and India. ${ }^{3}$

The re-emergence of China as a major global power has led to considerable debate over the likely consequences for the rest of the world. Economically, the positive view highlights the major contribution that China has made to the growth of the global economy, particularly with its continued expansion in the aftermath of the credit crunch, which has prevented a more severe global recession. Critics, however, have argued that China, with its large trade surplus, has been a major source of global imbalances and hence has contributed to the instability of the global economy.

There are also debates over the geopolitical implications of China's rise. One view sees China as a threat to the United States' position as the sole superpower after the ending of the Cold War. This challenge to US hegemony

1 Calculated from United Nations Conference on Trade and Development (UNCTAD), World Investment Report, 2009: China Country Fact Sheet, available at www.unctad.org/sections/ dite_dir/docs/wirog_fs_cn_en.pdf.

2 Alan Winters and Shahid Yusuf, Dancing with Giants: China, India and the Global Economy (Washington DC, 2007), Table i.I.

3 The term BRICs was coined by Goldman Sachs' chief economist, Jim O'Neill, in 200r. The first official summit between the leaders of the BRICs was held in Russia in 2009. 
is seen as a cause of instability and potential conflict in the future. The official Chinese position, in contrast, emphasises China's 'peaceful rise' and seeks to downplay any potential conflict. ${ }^{4}$ Although many are sceptical about Chinese rhetoric in this regard, this more optimistic view of the political implications of China's global expansion is partly shared by some commentators.

The debate on the economic impact of China on the developing world began at the time of China's accession to the WTO in 200 I. Initially, a major focus of attention was the likely effect of Chinese competition on exports from other developing countries to markets in the developed world. ${ }^{5}$ More recently, a great deal of attention has been paid to the growing presence of China in Africa. ${ }^{6}$ This has focused not only on the economic impacts but also on the political implications of China's relations with states such as Sudan, Angola and Zimbabwe. There is also now a growing literature on the impacts of China on Latin America, although, at least in Europe, this has attracted rather less attention than China's involvement in Africa. ${ }^{7}$

As is the case with the literature on the global implications of Chinese expansion, there are contrasting views concerning China's impact on the developing world. The optimistic view stresses the significance of the growing Chinese market for exporters in the South and the contribution made by increased Chinese demand for raw materials to the commodity boom after 2002, which benefited many developing countries. It also points to the contribution made by Chinese aid and investment to building infrastructure in developing nations. Economically, the Chinese economy is seen as complementary to those of other developing countries that stand to gain from China's growth. Politically, the optimists see China as offering an alternative to the domination of the old colonial powers in Africa or the

4 Jiang Shixue, 'The Chinese Foreign Policy Perspective', in Riordan Roett and Guadalupe $\mathrm{Paz}$ (eds.), China's Expansion into the Western Hemisphere: Implications for Latin America and the United States (Washington DC, 2008), pp. 27-43.

5 See for example, Mehdi Shafaeddin, 'The Impact of China's Accession to WTO on the Exports of Developing Countries' (UNCTAD Discussion Paper no. I6o, Geneva, 2002); and Yongzheng Yang, 'China's Integration into the World Economy: Implications for Developing Countries' (IMF Working Paper WP/03/245, Washington DC, 2003).

6 On China's growing relations with Africa, see, for example, Andrea Goldstein et. al., China and India: What's in it for Africa (Paris, 2006); Rhys Jenkins and Chris Edwards, 'The Economic Impacts of China and India on Sub-Saharan Africa: Trends and Prospects', Journal of Asian Economics, vol. 17, no. 2 (2006), pp. 207-25; Chris Alden, China in Africa (London, 2007); Harry G. Broadman, Africa's Silk. Road: China and India's New Economic Frontier (Washington DC, 2007). Recently two special issues of journals have been devoted to the role of China in Africa: see Review of African Political Economy, vol. 35, no. I (2008); and European Journal of Development Research, vol. 2 I, no. 4 (2009).

7 An interesting comparison could be made between China's role in Latin America and its role in Africa, where despite certain parallels in terms of the economic links that have developed, there are significant political differences in terms of governance structures and the role of the United States. For reasons of space, this will not be attempted here. 
United States in Latin America. Particularly in Africa, this is reflected in the tendency for Chinese aid to involve far fewer conditions than those imposed by Western donors. Even for Latin America, the emergence of China can be seen as a counterweight to US influence in the region.

There is, however, a more pessimistic view of the impact that China is having on the rest of the developing world. This emphasises the competition between China and other developing economies. China represents a threat to the exports of other Southern exporters of manufactures, while imports from China compete with producers on the domestic market. China's high level of competitiveness in manufactured goods and its booming demand for primary products is tending to push other developing countries back into specialising in commodities, which do not provide the same dynamic benefits as the manufacturing sector. Chinese investment simply serves to reinforce this specialisation, while at the same time other foreign investors divert their investment from other developing countries to China. Politically, the pessimistic view sees China as undermining a trend towards increased democratic governance in the developing world, both through its example of successful economic development under an authoritarian political regime and through its support of repressive governments that violate human rights.

This Commentary examines these debates in the context of China's impact on Latin America. The next section describes the growth of relations between China and the region, and the drivers that have contributed to closer economic and political ties. This is followed by an examination of the main ways in which China has affected the economies of the Latin American countries. A similar discussion of the political implications of the rise of China then follows. The conclusion suggests that the optimists have exaggerated the economic benefits of the growth of China for the region while playing down some of the more problematic aspects of the relationship. On the other hand, in the political sphere it is the pessimists who have been most prone to exaggeration in their claims that China is having a negative impact on the region.

\section{Growing Relations between China and Latin America}

Links between China and Latin America really took off from the late i99os but only began to attract significant global attention with the visit of the Chinese president, Hu Jintao, to several Latin American countries and to the summit of the Asia-Pacific Economic Forum, held in Chile in 2004. It was not until 2008 that the Chinese government issued its first policy paper on Latin America and the Caribbean. ${ }^{8}$

${ }^{8}$ People's Republic of China, Ministry of Foreign Affairs, China's Policy Paper on Latin America and the Caribbean (Beijing, 2008). 


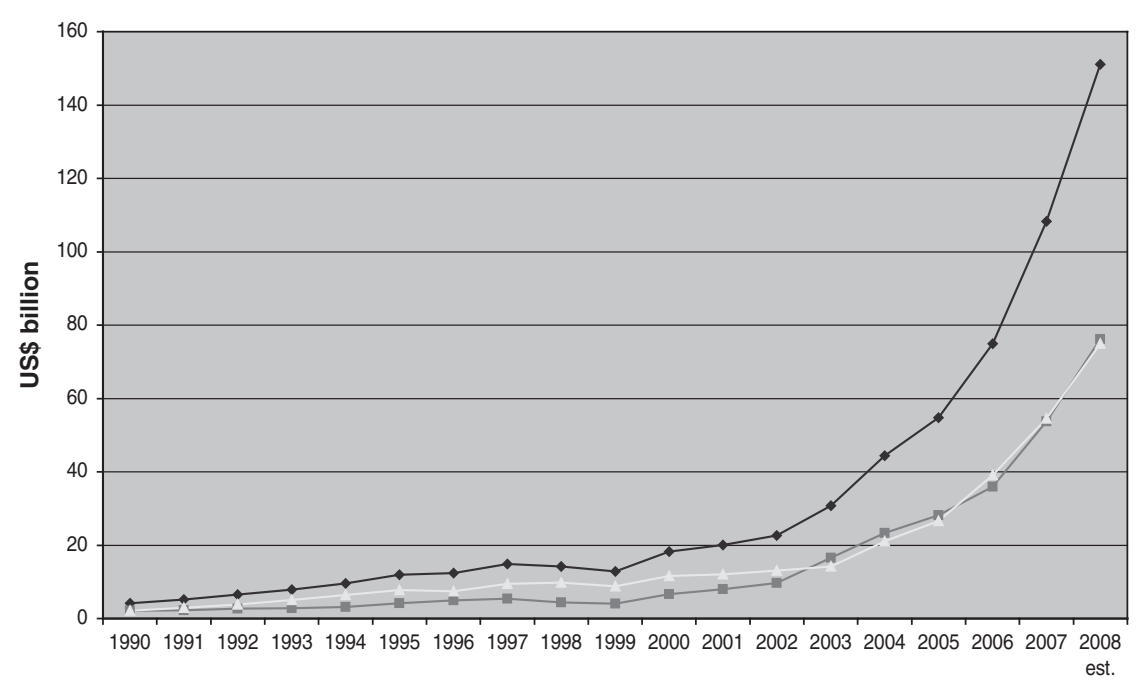

$\rightarrow-$ Total trade $\rightarrow-$ Imports from LA $\leadsto$ Exports to LA

Fig. I. China and Hong Kong's Trade with Latin America, I990-2008 (US\$ million). Source: author's elaboration from International Monetary Fund, Direction of Trade Statistics.

The most striking evidence of China's growing involvement in Latin America is the increased level of bilateral trade (see Figure I). Between I999 and 2008, total trade (exports plus imports) increased almost twelvefold to US\$ I 50 billion. As Figure I shows, Chinese imports from Latin America began to grow rapidly at the end of the I990s. China's rapid economic growth had, by the late I99os, outstripped domestic supplies of raw materials, and the country was becoming a net importer of a number of key commodities. China's exports to the region grew steadily during the I990s, reflecting the country's emergence as a global trading power, but then accelerated rapidly from 2003 onwards, following its accession to the WTO in December $200 \mathrm{I}$.

Trade is the dominant element in the economic relationship between Latin America and China. Although the visit of $\mathrm{Hu}$ Jintao to the region in 2004 was accompanied by expectations of large inflows of FDI from China, these never materialised. Chinese FDI flows to Latin America, excluding Caribbean tax havens such as the Cayman Islands and the British Virgin Islands, did increase sixfold between 2005 and 2007 , but they accounted for only about I per cent of total Chinese FDI outflows and a similar share of total FDI inflows to Latin America. ${ }^{9}$ Latin American FDI in China has been

9 Rhys Jenkins, 'The Latin American Case', in Rhys Jenkins and Enrique Dussel (eds.), China and Latin America: Economic Relations in the Twenty-First Century (Bonn, 2008), p. 42. 
even less significant: total bilateral flows, which came to around US\$ 400 million in 2007 , were dwarfed by total trade in the same year, at around US $\$$ Ioo billion. ${ }^{10}$

Similarly, Chinese aid, in the form of grants or concessionary loans, has not been very significant in Latin America. This is in marked contrast to Africa, where China has become a major donor. ${ }^{11}$ However, some of the smaller Latin American and Caribbean countries, including Costa Rica and Grenada, have received Chinese aid as part of China's competition with Taiwan to gain diplomatic recognition.

Closer economic ties with Latin America have been accompanied by stronger political links. China has signed 'strategic partnership agreements' with Venezuela (200I), Mexico (2003) and Argentina (2004), in addition to an earlier agreement with Brazil (I993). ${ }^{12}$ Over the past five years the number of countries in the region that recognise the PRC has increased with the establishment of diplomatic relations with Dominica (2004), Grenada (2005) and Costa Rica (2007); President Lugo in Paraguay announced after his election that he intended to recognise the PRC as well. ${ }^{13}$

China is also becoming increasingly involved in multilateral fora in the region. After initial resistance, it was accepted as a member of the InterAmerican Development Bank in 2008. It has also had permanent observer status at the Organization of American States since 2004. China is a member of the Forum for East Asia-Latin America Cooperation, established in 200 I, which brings together ministers and officials from 33 countries in the two regions. It has also initiated a series of dialogues with regional organisations such as Mercosur and the Andean Community.

What, then, have been the main drivers of closer links between China and Latin America? The rapid growth of Latin American exports to China from the end of the I990s was a result of the increased reliance of China on imports of key raw materials to fuel its industrial boom and to meet the changing food consumption patterns that accompanied higher income levels. This is reflected in the composition of the region's exports to China, a large and increasing proportion of which comprise unprocessed primary products such as copper, iron ore, crude oil and soybeans (see Table i).

10 Ibid.

${ }^{11}$ Congressional Research Service, China's Foreign Aid Activities in Africa, Latin America, and Southeast Asia (Washington DC, 2009), Table 3.

12 China adopts three labels to characterise its relations with other countries. They are, in descending order of importance, 'strategic partner', 'cooperative partner' and 'friendly cooperative relations': Jorge Domínguez, China's Relations with Latin America: Shared Gains, Asymmetric Hopes (Washington DC, 2006) p. 23.

13 In 2007 , following a change of government, St. Lucia switched its diplomatic recognition back to Taiwan, after ten years of recognising the PRC. 
Table I. Composition of Latin American Exports to China, 1995, 2001, 2006 $(\%$ share $)$

\begin{tabular}{|c|c|c|c|}
\hline & I995 & $200 \mathrm{I}$ & 2006 \\
\hline Primary products & 35.0 & 56.5 & 62.5 \\
\hline Manufactured goods & 65.0 & $43 \cdot 5$ & $37 \cdot 5$ \\
\hline \multicolumn{4}{|l|}{ Of which: } \\
\hline Resource-based & $43 \cdot 3$ & $2 \mathrm{I} .4$ & 22.8 \\
\hline Low-technology & IO.I & 6.5 & $3 \cdot 7$ \\
\hline Medium-technology & I0.4 & 8.3 & 6.3 \\
\hline High-technology & I.I & $7 \cdot 3$ & $4 \cdot 7$ \\
\hline Total & I00.0 & 100.0 & 100.0 \\
\hline
\end{tabular}

Source: Economic Commission for Latin America and the Caribbean.

The growth of these exports has been driven by Chinese demand rather than by any initiative from the Latin American side. Growing demand from China drove up the prices of key commodities from the region and provided a new market for exporters. China's interest in diversifying its sources of raw materials, and in securing a stable supply of those materials, led it to expand its imports from Latin America. From the point of view of the region, this was largely a windfall that it had done little to promote.

Chinese growth has relied heavily on exports, with the result that the expansion of foreign markets has been critical for the success of the model. The Chinese government had been seeking to join the WTO since its inception in 1995 and eventually did so in $200 \mathrm{r}$. Following its accession, China was granted most favoured nation treatment by the other WTO member countries, and although a number of Latin American countries insisted on measures to restrict Chinese imports for a transitional period of up to ten years, membership gave China better access to Latin American markets. This was followed by a surge in imports of Chinese-manufactured goods throughout the region.

China's access to Latin American markets has been a source of conflict, particularly in the more industrialised countries of the region. Local manufacturers have complained that they are adversely affected by Chinese competition, and this has led to anti-dumping measures being taken against Chinese goods. ${ }^{14}$ The Chinese government, on the other hand, has put pressure on Latin American governments to grant it 'market economy status' within the WTO, which would make it more difficult to prove dumping

14 See Andrés López and Daniela Ramos, 'The Argentine Case', in Jenkins and Dussel (eds.), China and Latin America, pp. 65-157; Daniel Saslavsky and Ricardo Rozemberg, 'The Brazilian Case', in Jenkins and Dussel (eds.), China and Latin America, pp. I 59-226. 
and thus to apply anti-dumping measures against Chinese imports. ${ }^{15}$ In recent years, Argentina, Brazil, Chile, Peru and Venezuela have all granted China this status. ${ }^{16}$

Thus, as in the case of Latin American exports to China, the growth of imports from China has also been largely promoted by China, leading to some resistance within the region to the growth of trade between the two countries, at least from some sectors. Where Latin American governments have been particularly keen to develop bilateral relations, in contrast, has been through FDI, particularly investment by Chinese firms in the region. But, as has been noted already, this is the area where local hopes and expectations have not been met, and China is still a long way from becoming a major source of investment in the region.

What Chinese FDI has taken place has been closely tied to the two main economic interests of China in the region: extractive industries, such as oil and mining, and assembly activities, which are a means of obtaining better access to the Latin American market. Examples of the former include the acquisition of Encana's oil and pipeline interests in Ecuador by Sinopec and PetroChina, CNPC's shareholding in PlusPetrol Norte in Peru, and Sinopec's investment in Omimex de Colombia. ${ }^{17}$ Market-oriented investments include Gree (air conditioners) and SVA (electronic products) in the Manaus free trade zone in Brazil, and TLC (TVs, air conditioners and electronic products) in Tierra del Fuego in Argentina. ${ }^{18}$

The development of the relationship between China and Latin America in areas other than the economic field has, in the main, been a result of closer economic relations between the two countries. There is one notable exception, however, which is in relation to Taiwan. Half the countries in the world which continue to recognise Taiwan are in Latin America and the Caribbean. These include Paraguay, the Dominican Republic, Haiti and some

15 In the case of a country which does not have market economy status, a complainant can prove dumping by comparing the prices charged for imports, in this case from China, with production costs in some other country, since costs in a non-market economy are not necessarily a good indication of real cost. When a country is recognised as a market economy, dumping can only be shown to occur when it sells goods at a price below their cost of production.

16 Congressional Research Service, China's Foreign Policy and 'Soft Power' in South America, Asia, and Africa (Washington DC, 2008), p. 26.

17 Duncan Freeman, Rhys Jenkins and Jonathan Holslag, 'Chinese Resources and Energy Policy in Latin America' (report prepared for the Development Committee of the European Parliament, EP/EXPOL/B/2006/33, 2007).

18 Alexandre Barbosa and Débora Miura Guimarães, 'Economic Relations between Brazil and China in the Consumer Electronic Sector' (University of East Anglia, programme on The Impact of China's Global Economic Expansion on Latin America, Working Paper no. 9, 2009), Table I4, available at www.uea.ac.uk/dev/faculty/Jenkins/china-latinamerica; López and Ramos, 'The Argentine Case'. 
other Caribbean islands, and all the Central American countries apart from Costa Rica. China has consistently sought to isolate Taiwan, although relations between the two have improved somewhat recently. Under the One-China policy, China refuses to have diplomatic relations with countries that recognise Taiwan; both countries thus compete for recognition, particularly from small, less developed nations where it is relatively cheap to obtain the allegiance of the government. ${ }^{19}$ This is a major driver of Chinese aid to countries in the region, particularly in Central America and the Caribbean. When China provided aid to build cricket stadiums in several Caribbean countries in the run-up to the 2007 World Cup, both Dominica and Grenada switched recognition from Taiwan to the PRC. ${ }^{20}$

In summary, then, the growing relations between China and Latin America have been primarily driven by economic factors and have been most significant in the area of trade. The main drivers of these developments have come from the Chinese side, and Latin America has been responding to agendas where China has been in the driving seat.

\section{The Economic Impacts of China's Expansion on Latin America}

There has been considerable debate in the literature over whether the impact of China has been predominantly positive or negative for Latin America. There are a number of different ways in which China potentially affects Latin American trade and investment. First, there is the direct impact of the growth of Chinese demand on the region's exports. Second, because of the size of the Chinese economy, it also has an impact on world prices, particularly for primary commodities which Latin America exports to other countries. Third, China's growing exports of manufactured goods compete with Latin American exports in other markets. Fourth, increased imports from China have an impact on Latin American consumers and producers in their domestic markets. Fifth, China is a major destination for FDI from other countries, which may affect FDI flows to Latin America. Finally, China is becoming an increasingly important source of FDI, particularly in developing countries.

Much of the analysis of the implications of China's rise has been framed by a discourse of the 'threats' (or 'challenges') and 'opportunities' for Latin America. The dominant optimistic view of the impacts of China emphasises

$19 \mathrm{He} \mathrm{Li,} \mathrm{'China's} \mathrm{Growing} \mathrm{Interest} \mathrm{in} \mathrm{Latin} \mathrm{America} \mathrm{and} \mathrm{its} \mathrm{Implications',} \mathrm{Journal} \mathrm{of} \mathrm{Strategic}$ Studies, vol. 30, no. 4 (2007), p. 487.

${ }^{20}$ Congressional Research Service, Comparing Global Influence: China's and US Diplomacy, Foreign Aid, Trade and Investment in the Developing World (Washington DC, 2008), pp. I62-3. 
the opportunities for the region and tends to minimise the threats. ${ }^{21}$ The emergence of China as a market has helped generate increased export revenues and improved terms of trade for the region, while the potential negative effects in terms of exports to other countries have been confined to a few countries and industries. Imports from China provide cheap consumer goods and also increase the competitiveness of local producers, who are able to acquire low-cost machinery and parts. China is seen as a potential source of capital to help make up the deficit in terms of investment in infrastructure in the region. There are also opportunities for attracting FDI to the region if Latin American countries can integrate into global production networks with China in the way that some of its Asian neighbours have done.

The pessimistic scenario, in contrast, is that the growing trade links between China and Latin America are reproducing the classic centre-periphery relations which Raúl Prebisch and the Economic Commission for Latin America criticised 50 years ago, with the region becoming increasingly specialised in primary commodity production while the manufacturing sector contracts in the face of increased Chinese competition both at home and abroad. ${ }^{22}$ Multinational companies relocate their plants from Latin America to China in order to take advantage of the large-scale production, low-cost labour and competitive exchange rate available there, diverting investment away from the region, while what little investment comes from China simply reinforces specialisation in primary products and creates very limited linkages with the local economy. In this view, the Latin American economies are caught in the middle between low-cost Chinese production and high-tech production in the North, resulting in a shrinking of their development space.

A third perspective stresses the differential effects of China on the South American economies, on the one hand, and Mexico, Central America and the Caribbean, on the other. ${ }^{23}$ This view sees the South American economies

21 See, for example, Robert Devlin, Antoni Estevadeordal and Andrés Rodríguez-Clare (eds.), The Emergence of China: Opportunities and Challenges for Latin America and the Caribbean (Washington DC, 2006); Daniel Lederman, Marcelo Olarreaga and Guillermo Perry (eds.), China's and India's Challenge to Latin America: Opportunity or Threat? (Washington DC, 2008); Jorge Blázquez-Lidoy, Javier Rodríguez and Javier Santiso, 'Angel or Devil? China’s Trade Impact on Latin American Emerging Markets', in Javier Santiso (ed.), The Visible Hand of China in Latin America (Paris, 2007), pp. 45-83.

22 See, for example Mauricio Mesquita Moreira, 'Fear of China: Is There a Future for Manufacturing in Latin America?', World Development, vol. 35, no. 3 (2007), pp. 35 5-76; Eva Paus, 'The Rise of China: Implications for Latin American Development', Development Policy Review, vol. 27, no. 4 (2009), pp. 419-56; Nicola Phillips, 'Consequences of an Emerging China: Is Development Space Disappearing for Latin America and the Caribbean?' (Centre for International Governance Innovation, Working Paper no. I4, Waterloo ON, 2007); Rhys Jenkins, 'El impacto de China en América Latina', Revista CIDOB d'Afers Internacionals, no. $85-6$ (2009), pp. 25 I-72.

23 Tomoe Funakushi and Claudio Loser, 'China's Rising Economic Presence in Latin America', Inter-American Dialogue (June 2005); Francisco González, 'Latin America in the 
Table 2. Contrasting Views of the Economic Impact of China on Latin America

Optimistic

Exports to third markets

Growth of the Chinese market

Increased commodity prices

Imports from China

Chinese FDI

FDI from other countries
Only a few Latin American countries are negatively affected in a small number of sectors

Increased foreign exchange earnings

Improved terms of trade

Reducing cost of living and investment costs through lower prices

Potential for improving infrastructure

Potential for integration of Latin America into global production networks involving China
Pessimistic

Many countries and sectors face competition from China in export markets

Reliance on a small number of primary product exports

Reinforcing specialisation in primary production; price volatility rather than secular improvement

Displacing domestic manufacturers and reducing employment

Low levels, tending to reinforce specialisation in primary commodities

Diversion of FDI from Latin America to China

Source: Author's elaboration.

which have expanded exports of primary commodities to China as major beneficiaries, while Mexico and Central America and the Caribbean, which face competition from Chinese manufactured goods in the US market and have not been major exporters to China, suffer potential negative impacts in terms of both trade and FDI flows.

Table 2 summarises the optimistic and pessimistic views of China's various economic impacts on Latin America. The remainder of this section discusses each of these impacts in turn.

\section{Chinese competition in export markets}

As was pointed out in the Introduction to this essay, the early studies of the impact of China on other developing countries were prompted by concerns over the effects on those countries' exports of China's entry into the W'TO. In the case of Latin America, this has been the most widely studied of the economic effects of China's rise. Most of the early studies were optimistic, concluding that, apart from Mexico, the countries of the region were less

Economic Equation - Winners and Losers: What Can Losers Do?', in Roett and Paz (eds.), China's Expansion, pp. I48-69; Osvaldo Rosales and Mikio Kuwayama, 'Latin America Meets China and India: Prospects and Challenges for Trade and Investment', CEPAL Review, no. 93 (2007), pp. 81-103. 
threatened by Chinese exports to third markets than were the Asian economies or the transition economies of Eastern Europe, and that the effects were confined to a few manufacturing industries. ${ }^{24}$ It was also argued that over time, 'LAC's trade specialization pattern is becoming more complementary to the specialization pattern of China ${ }^{25}$

However, other authors, using more recent data and different methods, have argued that the impact of China on Latin American exports has been both more severe, in the case of Mexico, and more widespread, in terms of the countries that have been affected, than this optimistic view suggests. ${ }^{\mathbf{2}}$ These studies suggest that China's accession to the WTO in 200 I and the elimination of import quotas for textiles and garments under the WTO Agreement on Textiles and Clothing in 2005 were followed by a significant increase in competition from China in developed country markets.

Using a methodology based on constant market share analysis developed by a Brazilian economist, Jorge Chami Batista, the loss of exports in the US market as a result of the increase in China's market share was estimated for I 8 Latin American countries for two periods, I 996-200 I and 200I-6 (see Table 3). ${ }^{27}$ The results shows clearly that while the impact of China on the region's exports was very limited up to China's accession to the WTO in 200I, after $200 \mathrm{I}$ exports to the United States from the I 8 countries were 9 per cent lower than they would have been if China had not increased its share of US imports. ${ }^{28}$

Table 3 shows the countries most affected by Chinese competition in the US market in the period between 200I and 2006. Mexico is third after the

24 Blázquez-Lidoy et al., 'Angel or Devil'; Devlin et al., The Emergence of China; Patricio Meller and Gabriela Contreras, 'La competitividad de las exportaciones chinas en los mercados de Estados Unidos y Japón' (CIEPLAN, Serie Estudios Socio/Económicos, no. 16, 2003); Daniel Lederman, Marcelo Olarreaga and Guillermo Perry, 'Latin America's Response to China and India: Overview of Research Findings and Policy Implications', in Lederman et al. (eds.), China's and India's Challenge to Latin America, pp. 3-35.

${ }^{25}$ Daniel Lederman, Marcelo Olarreaga and Eliana Rubiano, 'Latin America's Trade Specialization and China and India's Growth' (World Bank, Background Paper for the Office of the Chief Economist for Latin America and the Caribbean, Washington DC, 2006).

${ }^{26}$ Kevin Gallagher and Roberto Porzecanski, 'What a Difference a Few Years Makes: China and the Competitiveness of Mexican Exports', Oxford Development Studies, vol. 35, no. 2 (2007), pp. 219-23; Kevin Gallagher, Juan Carlos Moreno-Brid and Roberto Porzecanski, 'The Dynamism of Mexican Exports: Lost in (Chinese) Translation?', World Development, vol. 36, no. 8 (2008), pp. I 365-80; Moreira, 'Fear of China'; Rhys Jenkins, 'China's Global Growth and Latin American Exports' (UNU-WIDER Research Paper, no. 2008/104, Helsinki, 2008).

27 Jorge Chami Batista, 'Competition between Brazil and Other Exporting Countries in the US Import Market: A New Extension of Constant-Market-Shares Analysis', Applied Economics, vol. 40, no. I9 (2008), pp. 2477-87.

${ }^{28}$ For a fuller analysis see Jenkins, 'China's Global Growth'. 
Table 3. Latin American Countries Most Affected by Loss of Exports to China in the US Market, 1996-200I, 200I-6 (\% of Country's Exports to the US)

$\begin{array}{lcr} & \text { I996-200I } & \text { 200I-6 } \\ \text { Argentina } & -\mathrm{I} .8 & -5 . \mathrm{I} \\ \text { Brazil } & -4 . \mathrm{I} & -7.7 \\ \text { Costa Rica } & -\mathrm{I} .3 & -7.8 \\ \text { Dominican Republic } & -2.4 & -\mathrm{I} 3.0 \\ \text { El Salvador } & 6.5 & -\mathrm{I} 2.3 \\ \text { Guatemala } & 6.2 & -\mathrm{I} 0.5 \\ \text { Honduras } & 3.8 & -7.7 \\ \text { Mexico } & -\mathrm{I} . \mathrm{I} & -\mathrm{I} .4 \\ \text { Paraguay } & -6.9 & -9.7 \\ \text { Uruguay } & -5.8 & -9.3 \\ \text { Total for I8 Latin American countries } & -\mathrm{I} .0 & \end{array}$

Source: Own elaboration from United States International Trade Commission data available at dataweb.usitc.gov.

Dominican Republic and El Salvador. Other Central American countries are also among the most severely impacted, while even the countries of Mercosur have lost market share to China in the United States. Countries not listed, such as the Andean countries, have been relatively unaffected, reflecting the fact that the bulk of their exports to the United States are of primary products and resource-based manufactures, which do not compete with Chinese exports of manufactured goods.

Thus the competitive threat from China, far from being restricted to a few countries and diminishing over time, is both widespread and increasingly significant. This is certainly more in line with the perceptions of the private sector in the region than with the optimistic views put forward by the international institutions. ${ }^{29}$

The debate over the impacts of China on Latin American exports takes nation-states as the key units for analysis and regards the 'threats' as being at the country level. It should be noted, however, that changing trade patterns often result from the strategies of multinational corporations over the allocation of production and do not reflect the outcome of competition between firms based in different countries. The case of the 'threat' posed by China to personal computer (PC) exports from Mexico to the United States illustrates this very clearly. Between $200 \mathrm{I}$ and 2006 China's share of US imports of PCs,

${ }^{29}$ See the analysis by the Federação das Indústrias do Estado de São Paulo (FIESP), A ascensão chinesa e os prejuizos às exportaçoes brasileiras para os Estados Unidos (Sao Paulo, 2007). See also the reports from various Latin American countries by Helen Murphy, Christopher Swann and Mark Drajem, 'Economic Outlook: Competition from China Squeezes Developing Countries', International Herald Tribune, 2 April 2007. 
peripherals and parts more than trebled from I 4.2 per cent to 45.5 per cent, while Mexico's fell by almost half, from I 3.9 per cent to 7.5 per cent. ${ }^{30}$ This was, to a large extent, the result of several multinational firms, such as IBM, Hewlett-Packard and Selectron, transferring production to China. In these circumstances, where capital is globalised, the main losers from 'Chinese' competition are the workers who lose their jobs or see their wages and working conditions deteriorating. This reality is obscured by an approach that takes nation-states as its focus.

The example of the PC industry also illustrates the close connection that may exist between competition in export markets and diversion of FDI flows, which have tended to be analysed separately in the existing literature on China and Latin America. When a US multinational takes a strategic decision to relocate certain products or production processes from Mexico to China to supply the US market, this is reflected both in changes to the share of Mexico and China in US imports and in changes to the flows of FDI from the United States to Mexico and China. A global value chain analysis brings out these interconnections in a way that approaches based on trade and investment flows between countries do not. ${ }^{31}$

\section{Exports to China}

The rapid expansion of the Chinese market has made a significant contribution to the growth of Latin America's exports from the late ig9os. The elasticity of Chinese demand for imports from the region was found by Daniel Lederman et al. to be high, indicating a major dynamic boost for the area. $^{32}$ China is now one of the top three export markets for a number of Latin American countries. ${ }^{33}$

It is also worth noting, however, that not all the countries of the region have shared in this export growth. In 2008 China accounted for over Io per cent of the total exports of seven Latin American countries

Enrique Dussel, 'The Mexico-China Economic Relationship in Electronics: A Case Study of the PC Industry in Jalisco' (University of East Anglia, programme on The Impact of China's Global Economic Expansion on Latin America, Working Paper no. 5, 2008), available at www.uea.ac.uk/dev/faculty/Jenkins/china-latinamerica.

${ }^{31}$ For a brief account of this and other related approaches, see Jennifer Bair, 'Global Commodity Chains: Genealogy and Review', in Jennifer Bair (ed.), Frontiers of Commodity Chain Research (Stanford CA, 2009), pp. I-34.

32 Daniel Lederman, Marcelo Olarreaga and Isidro Soloaga, 'The Growth of China and India in World Trade: Opportunity or Threat for Latin America and the Caribbean?' in Lederman et al., China's and India's Challenge, pp. Iо I-20.

${ }^{33}$ Economic Commission for Latin America and the Caribbean, Economic and Trade Relations between Latin America and Asia-Pacific: The Link with China (Santiago, 2008), Table III.3. 
(Argentina, Brazil, Chile, Costa Rica, Cuba, Peru and Uruguay), but for other countries in the region its significance was relatively minor. ${ }^{34}$

Some authors have raised concerns over the pattern of specialisation in trade between Latin America and China ${ }^{35}$ Not only have the bulk of exports been of primary products and resource-based manufactures, but their share, particularly of the least processed products, has increased over time (see Table I). A related concern is that exports to China from the region are further concentrated in a narrow range of commodities (copper, iron ore, soybeans) and show little sign of diversifying.

It might be argued that the large share of primary products in Latin American exports to China is simply a reflection of comparative advantage based on factor endowments: Latin America is endowed with natural resources, while China has an abundance of labour. It would be a mistake to think of comparative advantage as a given, however. Like other East Asian countries before it, China has been actively creating a comparative advantage in key sectors. ${ }^{36}$ It has used a range of trade and industrial policies to develop certain stages of global value chains within China, which has led to Latin American producers increasingly specialising in the early, low-value-added stages of the chains.

An illustration of this has been the development of the soybean value chain which supplies the growing demand for animal feed and vegetable oil in China. ${ }^{37}$ Although Argentina's total exports of soybeans and soybean products to China have increased rapidly since the late I990s, this growth has been very unevenly distributed, with exports increasing most in the case of unprocessed soybeans while soybean meal exports to China have virtually disappeared. Compared to Argentina's exports to the rest of the world, its exports to China are much more heavily concentrated in the early stages of the value chain. This is explained by the decision of the Chinese authorities in the late r 990 s to develop a local oilseed crushing industry. Several promotional measures were implemented to encourage investment in the industry and to increase its competitiveness. A number of modern crushing

Own estimates based on IMF, Direction of Trade Statistics, available at www2.imfstatistics. $\operatorname{org} / \mathrm{DOT} /$.

${ }^{35}$ Sanjaya Lall and John Weiss, 'China's Competitive Threat to Latin America: An Analysis for 1990-2002', Oxford Development Studies, vol. 33, no. 2 (2005), pp. 163-94; Moreira, 'Fear of China'.

36 See Dani Rodrik, 'What's So Special about China's Exports?' (NBER Working Paper no. Wi 1947,2006 ).

37 This discussion is based on Andrés López, Daniela Ramos and Cecilia Simkievich, 'A Study of the Impact of China's Global Expansion on Argentina: Soybean Value Chain Analysis' (University of East Anglia, programme on The Impact of China's Global Economic Expansion on Latin America, Working Paper no. 2, 2008), available at www.uea.ac.uk/ $\mathrm{dev} /$ faculty/Jenkins/china-latinamerica. 
plants were established, most of them located in the coastal provinces, near the ports, to ensure easy access to imported raw materials Leading multinational companies such as ADM, Bunge and Cargill, which possessed crushing plants in Argentina, invested in China and now import soybeans from Argentina to supply their Chinese plants.

Evidence from the other major value chains in which Latin America is a significant exporter to China suggests a broadly similar pattern. In iron and steel, Brazil's trade with China shows an increasing specialisation in iron ore and concentrates as China rapidly develops its domestic steel industry; in copper, refining capacity has expanded in China with Chile exporting ore and cathodes. ${ }^{38}$ As in the case of competition in export markets, a detailed analysis of particular value chains can help us to understand better the processes that underlie the observed patterns of trade.

\section{China's impact on commodity prices}

Although it is generally recognised that the growth of Chinese demand was an important factor in the commodities boom of $2002-8$, the impacts on Latin America have not been analysed in any detail, except to point out that the region's terms of trade improved as a result of higher commodity prices. $^{39}$ Given the significance of China's demand for a number of key products which Latin America sells on the world market, the rise in the prices of these commodities is an important channel through which China's growth has affected the region. ${ }^{40}$

A detailed analysis of is commodities that Latin American countries export found that earnings were significantly higher in 2007 as a result of the effect of rapid Chinese growth on global demand. ${ }^{41}$ The bulk of these

38 Alexandre Barbosa and Débora Miura Guimarães, 'Economic Relations between Brazil and China in the Mining/Steel Sectors' (University of East Anglia, programme on The Impact of China's Global Economic Expansion on Latin America, Working Paper no. Io, 2009); Jonathan Barton, 'A Study of the Impact of China's Global Expansion on Chile: The Copper and Textile Value Chains' (University of East Anglia, programme on The Impact of China's Global Economic Expansion on Latin America, Working Paper no. 7,2009$)$. Both of these papers are available at www.uea.ac.uk/dev/faculty/Jenkins/ china-latinamerica.

39 On the commodities boom see, for example, UNCTAD, Trade and Development Report, 2005 (Geneva, 2005), chap. 2; IMF, World Economic Outlook, 2006: Financial Systems and Economic Cycles (Washington DC, 2006), chap. 5. One recent exception to the lack of detailed analysis in this area is Kevin Gallagher and Roberto Porzecanski, 'China and the Latin America Commodities Boom: A Critical Assessment' (University of Massachusetts, Political Economy Research Institute, Working Paper no. 192, 2009).

40 See Rosales and Kuwayama, 'Latin America Meets India and China', Table 2.

41 Rhys Jenkins, 'The Impact of China's Growth on Global Commodity Prices and Latin American Export Earnings', CEPAL Review (forthcoming, 20I I). 
gains came from increased prices for oil and minerals, particularly copper and iron ore. Indeed, it was estimated that, for the region as a whole, these indirect effects were more important in terms of additional foreign exchange earnings than the growth of direct exports to China between $200 \mathrm{I}$ and $2007 .{ }^{42}$

There are two important implications of this analysis at the level of individual countries. Firstly, countries such as Bolivia, Ecuador, Colombia and Venezuela, which historically exported little to China, nevertheless benefited from the higher world prices for their oil, gas and minerals that resulted from the growth of Chinese demand. Secondly, however, countries which are net importers of oil and minerals were losers as a result of China's impact on commodity prices. Most of the Central American countries and Uruguay found themselves in this position. ${ }^{43}$ Since the Central American countries are also among those most affected by competition from China in the US market, this reinforces the view that they have been negatively affected by the growth of China.

\section{The growth of imports from China}

Despite the fact that competition from Chinese imports is the most politically sensitive aspect of closer relations as far as a number of Latin American countries are concerned, it has received comparatively little attention in the academic literature. The extremely rapid growth of imports from China since 2003 has given rise to complaints of 'unfair competition' and accusations of dumping from local manufacturers, and, as noted above, has led to some Latin American governments adopting protectionist measures. ${ }^{44}$

The major concern is that Chinese imports are displacing local production and jobs, but how justified is this fear? In contrast to the case of exports to China, all the Latin American countries, even those which do not have diplomatic relations with the PRC, have seen China's share in their total imports increase significantly. Because this is a relatively recent phenomenon, however, there has been little empirical analysis of the impact of Chinese imports, and the few studies that have been carried out do not cover the recent surge in imports. For example, studies by Lucio Castro et al. on Argentina and Enrique Dussel on Mexico, which found very little evidence that imports from China reduced manufacturing employment significantly, only covered the period up to $2003 .{ }^{45}$ More recent evidence for Brazil

\footnotetext{
${ }^{42}$ Ibid. $\quad{ }^{43}$ Ibid., Table 5. $\quad{ }^{44}$ Murphy et al., 'Economic Outlook'.
}

45 Lucio Castro, Marcelo Olarreaga and Daniel Saslavsky, 'The Impact of Trade with China and India on Argentina's Manufacturing Employment', in Lederman et al. (eds.), China's 
and Argentina (up to 2006) suggests some negative impact of Chinese imports on domestic manufacturing, but this impact is limited to a few industries. ${ }^{46}$

It is argued in some quarters that the growth of imports from China has had a positive impact in Latin America, increasing the competitiveness of local manufacturers through cheaper inputs and low-cost machinery and equipment. ${ }^{47}$ While it is true that a significant proportion of the region's imports from China are indeed parts and capital goods, there have in fact been no studies to show what impact this has had on Latin American competitiveness.

A further issue that has emerged recently with the growth of imports from China has been the effect on regional integration. The growth of intraregional trade in Latin America has slowed down in recent years. There is also evidence that Brazil, particularly, is facing increased competition from China for its exports to Argentina and other regional markets. ${ }^{48}$ This raises the question of how far the growth of imports from China has in fact contributed to the stagnation of the process of integration in the region.

Much of the evidence on the effects of increased imports from China is anecdotal, and this is an area which requires further research. What is clear is that the rapid growth of imports has led to a change in the balance of trade. Whereas China had a trade deficit with Latin America between 2003 and 2005 , the recent growth of imports has led to a surplus in its trade with the region. Even countries with significant commodity exports to China, such as Argentina and Brazil, are now in deficit. This has been reflected in a less favourable view among the public of the implications of China's economic growth, particularly in Argentina. ${ }^{49}$

\section{Impacts on foreign direct investment}

There are two ways in which Chinese growth potentially affects FDI in Latin America. The first involves Chinese inward investment in the region.

and India's Challenge to Latin America, pp. 269-90; Enrique Dussel, 'The Mexican Case', in Jenkins and Dussel (eds.), China and Latin America, pp. 279-385.

46 Jenkins, 'The Latin American Case'.

47 Conselho Empresarial Brasil-China, China-Brazil Trade Report, Year I, Issue I (Rio de Janeiro, 2008), p. 4.

48 Daniel Sica, 'Algunos elementos de análisis sobre la presencia de China en la relación Argentina-Brasil', Economía Online (www.abeceb.com) (2007); Barbosa and Guimarães, 'Consumer Electronic Sector'.

49 Pew Global Attitudes Poll, May 2008, quoted in David Shambaugh, 'China's Multidimensional Thrust into the Latin American Region' (address to Third International Conference of the China-Brazil Business Council, 'China's Presence in Latin America', São Paulo, 30 June 2009). 
Despite high expectations of significant inflows for a number of years, as indicated above, these have remained relatively low until now and have mainly been driven by the same factors as trade: the acquisition of raw materials and access to the Latin American market for Chinese exports.

A more interesting question is that of the impact that the growth of China has had on FDI flows from other countries to Latin America. The main concern here has been the potential diversion of FDI from the region as a result of the increased attractiveness of China as a destination for foreign firms. ${ }^{50}$ Similar worries were voiced in Asia, particularly in the Association of Southeast Asian Nations (ASEAN) countries, at the time of China's accession to the WTO. ${ }^{51}$ Subsequent studies have failed to find evidence of significant diversion of FDI from other Asian countries to China, however, and several have even found a positive relationship between FDI flows to China and to some of its neighbours. ${ }^{52}$ This is generally interpreted as reflecting a complementarity between China and other Asian economies arising from their integration into regional or international production networks.

In Latin America, the prima facie case that the growth of China has led to a diversion of FDI is based on the observation that inflows to China grew rapidly in the r 990 s while investment in Latin America and the Caribbean lagged behind. Cravino et al. point out, however, that the lag was mainly during the period between 1990 and 1997 , and that since then Latin America has performed rather well relative to China in attracting FDI. ${ }^{53}$ In any case, any such correlation does not necessarily indicate a causal relationship.

Several empirical studies have attempted to test the FDI diversion thesis for Latin America more systematically, but with mixed results. Some

50 Gabriel Correra López and Juan González García, 'La inversión extranjera directa: China como competidor y socio estratégico', Nueva Sociedad, no. 203 (2006), pp. I I 4-27.

${ }^{51}$ See the statements by Mahatir Mohamad, former prime minister of Malaysia, and Supachai Panitchpakdi, former deputy prime minister of Thailand, quoted in Benoit Mercereau, 'FDI Flows to Asia: Did the Dragon Crowd Out the Tigers?' (IMF Working Paper WP/05/i89, Washington DC, 2005).

${ }^{52}$ Barry Eichengreen, and Hui Tong, 'Is FDI to China Coming at the Expense of other Countries?' (NBER Working Paper no. I I335, 2005); Busakorn Chantasasawat, K. C. Fung, Hitomi Lizaka and Alan Siu, 'The Giant Sucking Sound: Is China Diverting Foreign Direct Investment from Other Asian Economies?', Asian Economic Papers, vol. 3, no. 3 (2005), pp. I 22-40; Chengang Wang, Yingqi Wei and Xiaming Liu, 'Does China Rival its Neighbouring Economies for Inward FDI?’, Transnational Corporations, vol. I6, no. 3 (2007), pp. 35-6o.

53 Javier Cravino, Daniel Lederman and Marcelo Olarreaga, 'Foreign Direct Investment in Latin America during the Emergence of China and India: Stylized Facts', in Lederman et al., China's and India's Challenge to Latin America, pp. I 2 I-42. 
find that FDI in China had a negative impact on FDI in Latin America, particularly in Mexico, while others find no discernable effect. ${ }^{54}$ Only one study finds a positive relationship between FDI in China and in Latin America. ${ }^{55}$ It is difficult to argue that this study reflects the integration of Latin America into global production networks involving China, however, particularly since there was no positive relationship when the relationship between investment in China and in Latin America was tested using data on US manufacturing FDI in the two regions.

These studies differ in terms of their methodology, time period and countries covered, making it difficult to compare their results. They all involve a relatively high level of aggregation which may hide significant impacts on individual countries or sectors. This suggests a need for further work on this issue, particularly case studies of countries and sectors where diversion is most likely to take place. ${ }^{56}$

\section{Political Implications of China's Economic Expansion}

There is little doubt that the economic links between China and Latin America will continue to grow as China becomes an even more significant actor in the global economy. What, then, are the likely political implications of this for the region?

Four aspects of the political economy implications of China's impact on Latin America are of particular significance. First, how will the rise of China affect US hegemony in the region? Closely related to this is the effect of Latin America's growing relationship with China on the autonomy and bargaining power of the Latin American states internationally, and particularly in relation to the United States. Third, what are the implications of Latin America's growing relations with China for democracy in the region? Finally,

54 Alicia García Herrero and Daniel Sanatabárbara, 'Does China Have an Impact on Foreign Direct Investment to Latin America?’, in Santiso (ed.), The Visible Hand, pp. 133-59; José Luis de la Cruz, Antonina Ivanova Boncheva and Antonio Ruiz-Porras, 'Competition between Latin America and China for US Direct Investment', Global Economy Journal, vol. 8, no. 2 (2008), pp. I-20; Busakorn Chantasasawat, K. C. Fung, Hitomi Lizaka and Alan Siu, 'Foreign Direct Investment in East Asia and Latin America: Is there a People's Republic of China Effect?' (Asian Development Bank Institute, Discussion Paper no. 17, Tokyo, 2004); Eichengreen and Tong, 'FDI to China'. Chantasasawat et al. find no impact on the level of FDI in Latin America; they do find an impact on Latin America's share of total FDI in developing countries, but argue that China is not a major factor in this.

55 Javier Cravino, Daniel Lederman and Marcelo Olarreaga, 'Substitution between Foreign Capital in China, India and the Rest of the World: Much Ado about Nothing' (World Bank, Background Paper for the Office of the Chief Economist for Latin America and the Caribbean, Washington DC, 2006).

56 The case study of the Mexican PC industry discussed earlier is a good example of such work. 
will China's influence strengthen the role of the state in Latin America's economies and lead to a shift away from neoliberalism in the region?

\section{China's challenge to the hegemony of the United States}

The Right in the United States sees China's growing involvement in Latin America as a significant threat. Congressman Dan Burton, in a statement at a hearing before the House of Representatives' Subcommittee on the Western Hemisphere, stated:

I am very concerned with the rise of influence China is pursuing in our Hemisphere and I believe it is important that the United States grasps the economic, social and national security implications of a Latin America under the thumb of China. Once China is able to move in and expand control, it will be difficult to turn the tide. ${ }^{57}$

Much US political analysis from a 'realist' perspective shares this deep suspicion of Chinese motives, seeing Chinese expansion as part of a geopolitical strategy to develop a multipolar international system in place of one that is dominated by a single superpower. ${ }^{58}$ As June Teufel Dreyer comments:

Markets and raw materials are only part of the attraction that Latin America holds for Beijing ... The larger and arguably more important motivation of Beijing's strategy is geopolitical, not economic. ${ }^{59}$

Stephen Johnson and Evan Ellis identify competition with the United States as one of the key areas of interest for China in expanding its involvement in Latin America, along with economic interests and isolating Taiwan. ${ }^{\mathbf{6 0}}$ Ellis also highlights the ways in which the growing presence of China is increasing the constraints on US operations in Latin America. ${ }^{61}$

An alternative view sees Chinese interests in Latin America as part of China's 'going global' policy - in other words, as primarily economic. Political and military relations are seen as following on from closer economic ties, which are the main focus of Chinese diplomacy in the region. ${ }^{62}$ It is pointed out that the Chinese government has been very careful not to be

57 Congressman Dan Burton, Statement before the Subcommittee on the Western Hemisphere of the Committee on Foreign Affairs, 'The New Challenge: China in the Western Hemisphere' (Washington DC, 2008).

58 Xiang Lanxin, 'A Geopolitical Perspective on Sino-Latin American Relations', in Cynthia Arnson, Mark Mohr and Riordan Roett (eds.), Enter the Dragon? Cbina's Presence in Latin America (Washington DC, 2007), pp. 59-63; Xiang Lanxin, 'An Alternative Chinese View', in Roett and Paz (eds.), China's Expansion, pp. 44-58. I am grateful to an anonymous referee for emphasising the point about the realist perspective to me.

59 June Teufel Dreyer, 'The China Connection' (University of Miami, Center for Hemispheric Policy, China-Latin America Task Force, 2006), pp. I-2.

60 Stephen Johnson, 'Balancing China's Growing Influence in Latin America', The Heritage Foundation Backgrounder, no. I888 (2005); Evan Ellis, China in Latin America: The Whats and Wherefores (Boulder CO, 2009), chap. 2.

${ }^{61}$ Ibid., pp. 283-4. $\quad{ }_{62}^{6}$ Domínguez, China's Relations with Latin America, pp. 8-9. 
seen as challenging the United States in the region. ${ }^{63}$ Indeed, China recognises that the United States considers Latin America to be its backyard. ${ }^{64}$

Despite the rapid growth of trade between China and Latin America over the past decade, the United States and European Union remain more important trading partners for the region than China. For Latin America as a whole, trade with the United States is four times as important as trade with China, while trade with the EU is more than 50 per cent greater than that with China. ${ }^{65}$ As was shown earlier, China is even less significant in terms of FDI to Latin America; investment from the OECD countries accounts for the bulk of inflows to the region. Unlike the situation in aid-dependent African countries, there are limited opportunities in Latin America for China to increase its influence through grants and concessionary loans, except in the case of some of the small Central American and Caribbean countries. In those cases, however, China's main objective has been to get countries to switch diplomatic recognition from Taiwan to the PRC, rather than to undermine US hegemony.

China's main objectives in Latin America are to obtain secure sources of raw materials and market access for its manufactured goods. It therefore has an interest in continuing economic and political stability in the region, and would not want to undermine this through a confrontation with the United States. Populist nationalism in Latin America, although historically directed against the United States, could also adversely affect Chinese interests in the region. The Chinese ambassador to Ecuador, for example, expressed concerns over the implications for his country's oil interests of institutional uncertainties created by the revision of the country's constitution and bilateral investment agreements. ${ }^{\mathbf{6 6}}$

Another factor that influences China's policy towards the region is a recognition that its relationship with the United States is much more important to it than its relations with Latin America or any individual Latin American country, both economically and politically. ${ }^{67}$ As a result, China's policy towards the region has been pragmatic rather than ideological. Far from allying itself strategically with left-wing or populist governments in the region, the Chinese government has consistently tried to maintain good relations with

${ }^{63}$ See Li, 'China's Growing Interest'; Shixue, 'The Chinese Foreign Policy Perspective'; Juan Tokatlian, 'A View from Latin America', in Roett and Paz (eds.), China's Expansion, pp. 59-89; Barbara Stallings, 'The US-China-Latin America Triangle: Implications for the Future', in Roett and Paz (eds.), China's Expansion, pp. 239-59.

64 Shixue, 'The Chinese Foreign Policy Perspective', p. 40.

65 Calculated from IMF, Direction of Trade Statistics. Figures for 2008.

${ }^{66}$ Chinese ambassador to Ecuador, Cai Runguo, quoted in Ellis, China in Latin America, p. I 23.

67 Riordan Roett and Guadalupe Paz, 'Introduction: Assessing the Implications of China's Growing Presence in the Western Hemisphere', in Roett and Paz (eds.), China's Expansion, p. 2. 
both right-wing military regimes in the past and democratically elected governments of different political hues more recently. China has not been keen to be identified closely with the anti-US rhetoric adopted by President Chávez in Venezuela and has given more attention to its relations with countries with which it has important economic links, such as Brazil, Argentina and Chile. It also recognises the value of developing relationships with countries that will last in the longer term, and not being too closely associated with a particular regime which may not remain in power.

\section{Greater autonomy in Latin America}

What is seen as a threat from the US side may be regarded in Latin America as an opportunity to reduce dependence on the United States. There is, therefore, a parallel debate within Latin America over whether or not the presence of China gives greater autonomy and space for negotiation to the countries of the region. Sergio Cesarín and Martín Pérez Le-Fort see China's increasing global influence and its strategy of promoting multipolarity and multilateralism as an opportunity to counterbalance US power in the region. ${ }^{68}$ In contrast, Rafael Fernández de Castro and Laura Díaz Leal describe the belief that China can be a counterweight to the United States in Latin America, and especially in Mexico, as a 'false illusion'. ${ }^{69}$

China at present has neither the economic nor the military capacity to challenge US hegemony in the western hemisphere, nor is it in its interests to do so. This does not, however, mean that the growth of China does not provide a degree of increased autonomy for governments in Latin America. One example of this was the conflict over the American Service-Members' Protection Act, which required the suspension of military aid and training for countries that refused to agree not to prosecute US military personnel for war crimes. Fear that this would lead the countries affected to increase military cooperation with China led the US administration to re-authorise military training programmes for I I Latin American and Caribbean countries in $2006 .^{70}$

The diversification of economic links which the growth of China has made possible has, to some extent, reduced the Latin America's dependence

68 Sergio Cesarín, 'The Relationship between Latin America and China: Realities and Trends', in Aranson (ed.), Enter the Dragon?, pp. I7-25; Martín Pérez Le-Fort, 'China y América Latina: estrategias bajo una hegemonía transitoria’, Nueva Sociedad, no. 203 (2006), pp. 89-IOI.

69 Rafael Fernández de Castro and Laura Díaz Leal, 'Falsa ilusión: China, el contrapeso de Estados Unidos en el hemisferio occidental', in Enrique Dussel and Yolanda Trápaga (eds.), China y México: implicaciones de una nueva relación (Mexico City, 2007), pp. 105-17.

70 China-Latin America Task Force, 'Findings and Recommendations of the China-Latin America Task Force' (University of Miami, Center for Hemispheric Policy, 2006) p. 24 
on the United States, but this should not be exaggerated since, as was pointed out above, the United States remains far more important economically to the region than China. Indeed, for some countries it could be argued that the growth of China has led to increased dependence on the United States. This is most clearly the case in the Dominican Republic and the Central American countries, where one of the arguments put forward for signing the DR-CAFTA agreement with the United States was the threat posed by Chinese competition in the US market. ${ }^{71}$ Thus, paradoxically, the rise of China contributed to an agreement which ties the countries involved more closely to the United States.

\section{A threat to democracy?}

Some of those who believe that the rise of China is a threat to US geopolitical interests in Latin America also argue that China's growing influence is undermining democracy and free market policies in the region:

The Chinese model suggests that a society can lift itself out of poverty using a model of growth that is not necessarily democratic. Although many elements of the Chinese development model are not applicable to the Latin American case, the model sends out the message that discipline, not democracy, is the key to development and prosperity. ${ }^{72}$

This interpretation sees China's increasing involvement in Latin America as potentially undermining US efforts to promote political reform, human rights and free trade in the region, and as providing ideological support to anti-US, anti-democratic and anti-free market leaders in countries such as Ecuador and Nicaragua. ${ }^{73}$ Others dispute the claim that the success of China is undermining support for democracy in Latin America, arguing that China's internal political model is not particularly attractive to the region and that support for democracy remains strong there. ${ }^{74}$

There is little evidence to support the claim that Chinese involvement is undermining democracy in the region. Although it may be necessary to take China's claims of non-interference in the internal affairs of other countries with a pinch of salt, as argued above, China has adopted a pragmatic approach and has been prepared to do business with a variety of political regimes. The fact that concerns about the anti-democratic impacts

71 The Office of the US Trade Representative claimed that 'CAFTA would provide regional garment-makers ... a critical advantage in competing with Asia': CAFTA Facts: The Case for CAFTA (Washington DC, 2005), p. i.

72 China-Latin America Task Force, 'Findings and Recommendations', p. 2 I.

${ }^{73}$ Evan Ellis, 'The Military-Strategic Dimensions of Chinese Initiatives in Latin America' (University of Miami, Center for Hemispheric Policy, China-Latin America Task Force, 2006), p. 9.

74 Tokatlian, ‘A Latin American View', p. 64. 
of China's presence are voiced particularly vehemently by sections of the political Right in the United State, which has in the past supported authoritarian regimes in the region, merely reinforces scepticism over these claims.

\section{An alternative economic model?}

China's economic model, with its emphasis on a strategic role for the state, is seen by a number of authors as offering important lessons for the region. ${ }^{75}$ As Alex Fernández-Gilberto and Barbara Hogenboom argue, 'China's rise shows developing countries that there are viable alternatives to the Washington Consensus'. ${ }^{76}$ Although China liberalised its economy, the policies adopted were endogenously driven rather than being imposed externally, as was the case with the Washington Consensus in Latin America. As a result, the Chinese state was able to regulate and control the process of globalisation of the Chinese economy. In Latin America, conversely, extensive liberalisation, deregulation and privatisation of the economy reduced the ability of the state to exercise significant control over it.

The impact of China on development strategy in Latin America is contradictory. In objective terms, China's rise has intensified the trend towards increased reliance on exports of primary products, the threat to domestic manufacturing and the narrowing of the 'development space' for the region which began with the neoliberal reforms of the $1980{ }^{77}{ }^{77}$ Ideologically, however, increased awareness of China's success and the poor economic performance of most Latin American countries that took up the policy recommendations of the Washington Consensus have reopened the debate over development strategy in the region. There has been growing talk of the 'Beijing Consensus', although its precise content remains unclear. ${ }^{78}$ This raises the question of whether China represents an alternative model for Latin America, and if so, what are the key features of that model and the lessons to be learnt?

A number of political leaders in the region have spoken warmly of the Chinese model. In 2004 President Néstor Kirchner of Argentina expressed his admiration for China's economic achievements and indicated that

75 Robert Devlin, 'China's Economic Rise', in Roett and Paz (eds.), China's Expansion, pp. I I I-47; Paus, 'The Rise of China'.

76 Alex Fernández Gilberto and Barbara Hogenboom, 'Latin America and China: South-South Relations in a New Era', in Alex Fernández Gilberto and Barbara Hogenboom (eds.), Latin America Facing China: South-South Relations beyond the Washington Consensus (forthcoming). $\quad{ }^{77}$ See Phillips, 'Consequences of an Emerging China'.

78 A. Cha, 'China Uses Global Crisis to Assert its Influence', Washington Post Foreign Service, 23 April 2009. 
Argentina should learn from the Chinese example. ${ }^{79}$ During the Brazilian presidential elections of 2006, both President Lula and Geraldo Alckmin, the Social Democratic Party candidate, indicated that they were impressed with certain aspects of the Chinese development model. ${ }^{80}$

The lessons drawn from China in many ways parallel those from previous industrialisers in East Asia, namely the need to use strategic government intervention to develop national technological capabilities and the need for investment to expand domestic knowledge-based assets. ${ }^{81}$ While policies should be country- and context-specific, governments need to play an active role in shaping strategic priorities aimed at moving up the value chain. ${ }^{82}$ In effect, the Chinese experience is a further vindication of the 'developmental state' as a key to economic transformation.

\section{Conclusions}

Over the past three decades, China's re-emergence as a world power, rapid economic growth and integration with the global economy have been dramatic. Over the last decade this has started to impact on Latin America in a number of ways. The main driver of China's involvement in Latin America has been economic, reflected in the rapid growth of trade links. Until now FDI flows have lagged a long way behind trade, although they are likely to increase in the future. Closer political relations with China have in the main resulted from growing economic links, apart from the issue of Taiwan, where political concerns have driven economic relations.

This Commentary has reviewed the debate over the implications of China's growing global influence for Latin America. In terms of economic impacts, the view that China has been an 'angel' for Latin America is proving over-optimistic, and the concerns raised by the critics are real. Although some countries and some sectors in the region have benefited in the short and medium term from the booming Chinese demand for primary products, these benefits have not extended to all the countries of the region or necessarily been widely distributed within those countries where they have been attained. The concern that the growth of China is reinforcing specialisation in primary production which may be detrimental for long-term growth prospects is real, implying that the Latin American countries need to upgrade and diversify their exports to China.

79 (2006), pp. 62-88.

81

${ }^{81}$ For an earlier discussion of the implications of the experience of the East Asian newly industrialising countries for Latin America, see Rhys Jenkins, 'Learning from the Gang: Are There Lessons for Latin America from East Asia?', Bulletin of Latin American Research, vol. Io, no. I (I99I), pp. 37-54.

82 Paus, 'The Rise of China'. 
This paper has also shown that the optimistic view that plays down the negative impacts of Chinese competition on Latin American exports is not supported by the evidence for the period since China joined the WTO. More countries and more sectors in the region have been negatively affected than is commonly admitted in the academic literature. Despite the rapid growth of imports from China over the last few years, there has been relatively little research on the impacts of Chinese competition in the domestic market so far, although it has been a cause of political tensions between some Latin American countries and China. This is a key area requiring further research.

The low level of Chinese FDI until now has meant that its impact on Latin America has been limited, although as it increases in the future, the implications are likely to become an important area for research. More attention has been given to the impact of China on investment from other countries coming to Latin America, particularly in relation to the possibility of diversion from the region. The results of these studies have been mixed, but they have all been highly aggregated. A more fruitful approach for future research is likely to be case studies of particular value chains which investigate the ways in which leading firms have restructured their global operations and supply lines.

As argued earlier, China's political engagement with Latin America has been mainly driven by its economic interests. China has neither the desire nor the capacity to challenge US hegemony in the region, as some US politicians and commentators fear. While it is true that the emergence of China has enabled some Latin American countries to reduce their dependence on the United States, giving them slightly more room for manoeuvre, in other cases, most notably the DR-CAFTA countries, it has contributed to them becoming even more closely tied to the United States through the free trade agreement.

There is little evidence to support the claims that China is undermining democracy in Latin America, either through its support for undemocratic regimes or through its example as a successful model of economic development under an authoritarian regime. There is more evidence that some elements of the Chinese economic model are seen as attractive by some Latin American governments as an alternative to the Washington Consensus. This falls a long way short of adoption of any 'Beijing Consensus', however, and should be seen simply as a new example of a more activist role for the state, which has been called for by neostructuralists in Latin America.

Much of the debate on the impacts of China on Latin America has focused on the region as a whole. Some authors, however, have drawn a distinction between the South American countries, which have been the main beneficiaries economically, and Mexico and Central America and the Caribbean, where the negative impacts have been concentrated. This is a 
valuable corrective to some of the over-generalised claims often made about the impacts of China, but does not give a complete picture. Indeed, it tends to emphasise the difference between countries exporting primary commodities, which are seen as winners, and exporters of manufactures, who are the main losers. As already indicated, exporters of primary products may not benefit in the long term from the resulting specialisation. Furthermore, this view ignores completely the impact of Chinese competition in the domestic markets of the countries concerned. A more complete picture will only emerge with in-depth analysis of individual countries which takes into account all the different channels through which China affects their economies. $^{83}$

The debate on the impacts of China has also tended to give relatively little attention to the potential effects within countries, but there are clearly winners and losers within each country. The winners have been mainly large mining conglomerates (both state-owned and privately owned), commercial farmers and large-scale agribusiness. In many cases, where capital is internationally mobile, the main losers are likely to be industrial workers facing pressure from lower wages in China. Locally owned firms in the manufacturing sector may also be losers as they find their profit margins squeezed in domestic, regional and international markets as a result of Chinese competition. These differential impacts within countries also have political implications. Different interests adopt different positions vis-à-vis China and are active in domestic political debates. ${ }^{84}$ The impacts of China on different groups within countries and the political implications of the domestic alliances formed around these issues are important areas for future research.

\section{Spanish and Portuguese abstracts}

Spanish abstract. El rápido crecimiento de China y su creciente integración en la economía global durante las tres décadas pasadas han tenido impactos económicos

83 A number of individual country studies do already exist, particularly on Mexico. These include Enrique Dussel, Economic Opportunities and Challenges Posed by China for Mexico and Central America (Bonn, 2005); Omar Neme, La competencia entre México y China: la disputa por el mercado de Estados Unidos (Mexico City, 2006); Arturo Oropeza, China entre el reto y la oportunidad (Mexico City, 2006); Enrique Dussel (ed.), Oportunidades en la relación económica y comercial entre China y México (Mexico City, 2007); Dussel and Trápaga (eds.), China y México. On Argentina, see Carlos Tramutola, Lucio Castro and Pablo Monat, Cbina: Cómo puede la Argentina aprovechar la gran oportunidad (Buenos Aires, 2005).

${ }^{84}$ In Brazil, for example, the Federação das Indústrias do Estado de São Paulo (Federation of Industries of the State of São Paulo), which represents the country's major industrialists, has been highly critical of the economic effects of China on the country, while the Conselho Empresarial Brasil-China, which is largely made up of firms which export to China, has defended the relationship. 
significativos e implicaciones políticas para Latinoamérica. Este artículo revisa los debates sobre si estos impactos han sido positivos o negativos para la región. Sostiene que aquellos que enfatizan los impactos económicos positivos de China han sido muy optimistas al tiempo que relegan algunos de los impactos negativos asociados con la competencia china en la manufactura y el incremento de la especialización latinoamericana en productos primarios. Por otro lado, cuando tales debates se han centrado en la dimensión política, ha habido una tendencia a exagerar el grado de influencia de China en la región y los temores que ha despertado, particularmente entre los comentaristas norteamericanos.

Spanish keywords: China, Latinoamérica, comercio, inversión extranjera, competencia, hegemonía norteamericana, democracia

Portuguese abstract. O rápido crescimento da China e o aumento de sua integração com a economia global ao longo das três últimas décadas ocasionou impactos econômicos e implicações políticas significativas na América Latina. Este artigo examina o debate sobre esses impactos, avaliando se ao final foram positivos ou negativos para a região. Argumenta que aqueles que enfatizam os impactos econômicos positivos da China foram demasiadamente otimistas, ignorando alguns dos impactos negativos associados à competição chinesa com o setor de produção industrial e com a crescente especialização latino-americana em produtos primários. Por outro lado, ao focar as dimensões políticas, há uma tendência em exagerar tanto o alcance da influência chinesa na região quanto os receios que esta suscita, particularmente entre analistas norte americanos.

Portuguese keywords: China, América Latina, comércio, investimento estrangeiro, competição, hegemonia norte-americana, democracia 